\title{
Infliximab salvage therapy after cyclosporine in an acute flare of chronic ulcerative colitis
}

\author{
ECS Lam MD FRCPC ${ }^{1}$, RJ Bailey MD FRCPC 2
}

ECS Lam, RJ Bailey. Infliximab salvage therapy after cyclosporine in an acute flair of chronic ulcerative colitis. $\mathrm{C}$ an J G astroenterol 2003;17(3):198-200.

A Ithough infliximab (Remicade, Schering Canada Inc, Quebec) therapy has been well studied in steroid refractory $C$ rohn's disease, its use remains controversial in chronic ulcerative colitis. A 24-year-old woman with a 14-year history of well controlled left sided ulcerative colitis presented with an acute flare. Clinical, endoscopic and biopsy evidence of an acute flare of ulcerative pancolitis were present. There was no response to intravenous steroids but improvement was seen after receiving 14 days of intravenous cyclosporine $(4 \mathrm{mg} / \mathrm{kg} / \mathrm{day}$ continuous infusion). The patient was discharged from hospital with azathioprine $(2.5 \mathrm{mg} / \mathrm{kg} / \mathrm{day})$ and low dose oral cyclosporine (4 $\mathrm{mg} / \mathrm{kg} /$ day). She presented with worsening symptoms seven days after discharge. Because of the patient's unwillingness for surgery, she instead received two injections of infliximab $5 \mathrm{mg} / \mathrm{kg}$ at week 0 and week 2. A n initial response occurred, but her clinical improvement was not durable. Colectomy was performed four weeks later. This is the first report of infliximab as a salvage therapy in an acute flare of chronic ulcerative colitis following failure of cycl osporine.

Key W ords: C yclosporine; Infliximab; U Icerative colitis

\section{T hérapie de sauvetage à l'infliximab après un traitement infructueux à la cyclosporine chez une patiente souffrant d'une poussée de recto- colite hémorragique chronique}

RÉSU MÉ : M ême si le traitement à l'infliximab (Remicade, Schering Canada Inc. [Q uébec]) a fait l'objet d'études approfondies dans le contexte de la maladie de $C$ rohn réfractaire aux stéroïdes, son recours dans les cas de rectocolite hémorragique $(\mathrm{RCH})$ chronique soulève toujours la controverse. Une femme de 24 ans souffrant de RCH gauche bien maîtrisée depuis 14 ans est venue consulter pour un épisode aigu de maladie. L'examen clinique, I'endoscopie et la biopsie ont confirmé la présence d'une poussée de pancolite ulcérative. L'administration de stéroïdes par voie intraveineuse s'est montrée infructueuse, mais une amélioration a été observée après 14 jours de traitement à la cyclosporine intraveineuse ( $4 \mathrm{mg} / \mathrm{kg} / \mathrm{jour}$ en perfusion continue). La patiente a obtenu son congé de l'hôpital en ayant en main une ordonnance d'azathioprine ( $2,5 \mathrm{mg} / \mathrm{kg} / \mathrm{jour}$ ) et de cyclosporine à faible dose ( $4 \mathrm{mg} / \mathrm{kg} / \mathrm{jour}$ ) par voie orale. Sept jours plus tard, elle a consulté de nouveau pour une aggravation des symptômes. Devant le refus de la patiente de se faire opérer, on lui a plutôt administré deux injections d'infliximab à raison de $5 \mathrm{mg} / \mathrm{kg}$ à deux semaines d'intervalle. II y a eu réaction clinique favorable au début, mais l'amélioration n'a pas duré. U ne colectomie a été pratiquée quatre semaines plus tard. II s'agit du premier cas déclaré de thérapie de sauvetage à l'infliximab dans le contexte d'un épisode aigu de RCH après l'échec d'un traitement à la cyclosporine. ntravenous corticosteroids remain the initial therapy for a severe acute flare of chronic ulcerative colitis (CUC). Therapeutic options for patients who have failed a trial of steroids depend on the clinical scenario and, in part, patient preference. A Ithough colectomy is curative, patients who are not presenting with acute abdominal symptoms requiring surgery may elect to have a trial of medical therapy. Intravenous cyclosporine has been used to induce remission in patients with steroid refractory acute flares (1). A pproximately $18 \%$ to $43 \%$ of these patients fail to respond to cyclosporine and total proctocolectomy is the only therapeutic option $(1,2)$.

U Icerative colitis and C rohn's disease are idiopathic inflammatory conditions of the gastrointestinal tract. Differences in their proinflammatory and cytokine profiles have resulted in different emerging therapies for these two conditions. A common proinflammatory mediator early in the cytokine cascade is tumour necrosis factor alpha (TNF $\alpha$ ). Infliximab (Remicade,
Schering C anada Inc, Q uebec) is a chimeric monoclonal antibody against soluble and receptor based TN F $\alpha$. Its role in Chrohn's disease has been well established by impressive clinical trials for steroid refractory disease (3). However, the use of infliximab in cyclosporine refractory CUC is more controversial due to the lack of adequate clinical trials.

There appears to be a rationale for employing the same anti-T N F $\alpha$ strategy in steroid refractory CUC. In the animal model of CUC (cotton-top tamarins), neutralization of soluble TNF $\alpha$ with CDP 571 (a humanized soluble T N F $\alpha$ antibody) resulted in rapid clinical improvement (4). Limited human studies of anti-T NF $\alpha$ therapy for steroid resistant acute flares of CUC have also been performed. These studies did not include patients treated with cyclosporine before infliximab therapy $(5,6)$. We report a case in which infliximab was used as salvage medical therapy in a patient who failed intravenous cyclosporine therapy during an acute flare of CU C.

\footnotetext{
${ }^{1}$ D epartment of M edicine, U niversity of A lberta; ${ }^{2}$ D epartment of M edicine, Royal A lexandra H ospital, Edmonton, A lberta

Correspondence and reprints: Dr E ric C S Lam, D epartment of M edicine, Division of G astroenterology, $519 \mathrm{~N}$ ewton Research Building,

U niversity of A lberta, Edmonton, A lberta T 6G 2C 2. Telephone 780-407-8226, fax 780-407-3744, e-mail ericl@ualberta.ca

Receieved for publication September 9, 2002. A ccepted January 16, 2003
} 


\section{CASE PRESENTATION}

A 24 year-old white woman with CU C presented with a fiveday history of more than 12 large volume bloody diarrhea per day. She had crampy left lower quadrant abdominal pain and worsening fatigue over the preceding two weeks. There was no antecedent upper respiratory tract infection, nonsteroidal antiinflammatory medications or antibiotic use. She had significant tenesmus. There was no fever or chills. There were no extraintestinal manifestations of inflammatory bowel disease. She had flares of her ulcerative colitis every two years. Each flare in the past responded to steroid or mesalamine enema therapy. She was started on oral steroids (prednisone 40 mg/day) for the current flare and topical budesonide enemas with marginal impact on her symptoms. A fter one week of therapy, her bowel movements decreased to 10 per day. She was not improving as an outpatient and was hospitalized.

The patient was originally diagnosed with ulcerative colitis 13 years earlier when she presented with a history of intermittent rectal bleeding for one year. Endoscopic findings in 1989 revealed mucopurulent exudates with friability distal to the splenic flexure at the initial colonoscopy. There was no terminal ileal or cecal involvement. A small bowel follow through was also normal. Her ulcerative colitis had responded to steroids and she had been maintained on mesalamine ( $4 \mathrm{~g} /$ day). The patient was aware that colectomy would be curative but had al ways responded to medical therapy. She wanted to delay surgery until it was absolutely necessary. Yearly surveillance colonoscopy was started 10 years after the disease was diagnosed and all subsequent colonoscopies showed quiescent disease and no dysplasia on four quadrant biopsies every $10 \mathrm{~cm}$ in the left colon.

On presentation her blood pressure was $106 / 70 \mathrm{mmH} g$ with no postural drop. Her heart rate was 90 beats/min and she was afebrile. She weighed $46.7 \mathrm{~kg}$ and was $162 \mathrm{~cm}$ tall. She appeared ill and volume depleted. There was no lymphadenopathy or rashes. Cardiovascular examination revealed a II/VI systolic ejection murmur and jugular venous pressure was at the sternal angle. The respiratory examination was normal. Her abdominal examination showed no signs of peritonism but she had significant tenderness in the left lower quadrant and suprapubic region. Bowel sounds were present.

$\mathrm{Her}$ initial bloodwork on admission was white blood cell count $12.3 \times 10^{9} / \mathrm{L}\left(5.6 \times 10^{9} / \mathrm{L}\right.$ neutrophils, $11 \%$ bands), albu$\min 25 \mathrm{~g} / \mathrm{L}, \mathrm{C}$-reactive protein level $42.9 \mathrm{mg} / \mathrm{L}$. The abdominal radiograph showed a paucity of bowel gas and no thumbprinting. Her stool cultures and $\mathrm{C}$ lostridium difficile toxin assay were negative. Colonoscopy revealed mucopurulent exudates and ulceration continuous from the rectum to the mid ascending colon. A s a result of the above findings, she was started on $40 \mathrm{mg}$ intravenous methyl prednisolone twice a day.

$\mathrm{H}$ er bowel movement frequency decreased, but she was still having six to seven bowel movements per day with more than $50 \%$ of stools that were bloody. She was started on azathioprine $125 \mathrm{mg} /$ day $(2.5 \mathrm{mg} / \mathrm{kg} /$ day $)$ and intravenous cyclosporine $180 \mathrm{mg} /$ day ( $4 \mathrm{mg} / \mathrm{kg} /$ day) continuous infusion after 10 days of intravenous steroid treatment.

Intravenous cyclosporine was continued for 14 days. She felt well enough to be discharged from hospital. O n discharge, she was having three small diarrheal stools and her abdominal pain improved. She was discharged on azathioprine 125 $\mathrm{mg} /$ day $(2.5 \mathrm{mg} / \mathrm{kg} /$ day), cyclosporine (N eoral, N ovartis Pharmaceuticals, USA ) $175 \mathrm{mg}(3.75 \mathrm{mg} / \mathrm{kg} /$ day) and budes- onide enemas. She was required to have weekly complete blood counts and cyclosporine $\mathrm{C}_{0}$ levels.

The patient was readmitted a week later after worsening symptoms. She continued to be fatigued and had crampy lower abdominal pain. Her bowel movement frequency increased to 12 bloody bowel movements per day. A fter a frank discussion about the available options, the patient decided that she was not ready for colectomy. The patient knew that she may eventually require a colectomy but wanted to try medical therapy once more. Infliximab infusion ( $5 \mathrm{mg} / \mathrm{kg}$ ) was given. O ral cyclosporine was discontinued at the start of infliximab therapy.

W ithin two days, her bowel frequency decreased to three semi-formed, non-bloody stools per day and her abdominal discomfort improved. She was discharged on azathioprine 125 $\mathrm{mg} /$ day $(2.5 \mathrm{mg} / \mathrm{kg} /$ day). The patient had rel ief from her symptoms for approximately 10 days before relapsing with bloody diarrhea and fatigue. 0 utpatient laboratory exam 10 days after the infliximab revealed white blood cell count $6.1 \times 10^{9} / \mathrm{L}$, hemoglobin $86 \mathrm{~g} / \mathrm{L}$ and platelet count $709 \times 10^{9} / \mathrm{L}$. The patient received a second infliximab infusion $(5 \mathrm{mg} / \mathrm{kg}$ ) two weeks after the initial infusion. She did not have a clinical improvement from the second infusion and subsequently underwent colectomy.

\section{DISCUSSION}

This is the first reported case of using infliximab as salvage medical therapy following failure of intravenous cyclosporine. The clinical situation and patient preference for continued medical therapy resulted in the trial of infliximab. The patient responded with rapid clinical improvement over $48 \mathrm{~h}$ but the response lasted only 10 days before she relapsed. A second infusion did not make a clinical difference. This case demonstrates that infliximab is not the best option for acute severe CUC that is refractory to cyclosporine.

W hen should we regard an acute flare of $C U C$ as refractory to medical management? Chey et al (6) published a series of patients with steroid refractory CUC that improved clinically and endoscopically on a single infusion of infliximab (5 $\mathrm{mg} / \mathrm{kg}$ ). H owever, there were factors of the study that made it impossible to translate these results to our patient. The patient population in the $C$ hey study was older (average age 60 years, range 19 to 79 years) with some doubt in the diagnosis and a relatively short duration of disease (five of eight patients had disease for less than six years). Furthermore, none of the patients received cyclosporine before infliximab therapy. A nother study, published by Sands et al (5), was a placebocontrolled study testing infliximab at three doses $(5,10,20$ $\mathrm{mg} / \mathrm{kg}$ ) for steroid refractory CU C, that was terminated due to slow recruitment. A Ithough the baseline patient population characteristics more closely resembled the current case, study patients were excluded if they had cyclosporine in the three months before enrolment. Four of eight patients were considered treatment successes at two weeks. O ne patient who failed infliximab (5 mg/kg) subsequently had further medical therapy with intravenous cyclosporine. Some efficacy of infliximab in steroid refractory CUC was demonstrated but further study is needed.

There is little evidence to guide clinicians in the use of infliximab for patients who fail cyclosporine. M ost of the evidence centres on steroid refractory disease. Probert et al (7) studied the use of infliximab $5 \mathrm{mg} / \mathrm{kg}$ at week 0 and 2 versus placebo in steroid resistant ulcerative colitis. Twenty-two 
patients were randomly assigned to infliximab and 20 to the placebo group. A fter two and six weeks there was no statistical difference between the infliximab and placebo. Therefore, the use of infliximab in steroid refractory ulcerative colitis is of limited value. Patients with severe CU C refractory to intravenous steroids and intraven ous cyclosporine should be viewed as having disease that requires surgical management. If studies of infliximab on steroid refractory CUC find only marginal response, it would be reasonable to suggest that disease resistant to both steroids and cyclosporine would not respond to infliximab. Furthermore, Kugathasan et al (8) demonstrate the lack of infliximab clinical durability in steroid refractory ulcerative colitis. Outcomes of children and adults with steroid refractory ulcerative colitis who received a single dose ( $5 \mathrm{mg} / \mathrm{kg}$ ) of infliximab reveal that a partial response to infliximab is seen. H owever, of the nine patients that had a partial response, six had a colectomy by six months (8).

A fter an adequate response to intravenous cyclosporine, is there any role for continued immunosuppression with oral cyclosporine? In remission that is induced by intravenous cyclosporine, transition to oral cyclosporine titrating to blood levels has been used as a bridge to long term immunomodulatory therapy $(1,9)$. H owever, remission was not seen to extend beyond six months ( 1 ) and only one third of patients avoided colectomy (10). In a recent retrospective study of remission induced by intravenous cyclosporine, azathioprine alone was sufficient to maintain long-term remission to an average follow-up of 36 months (11). Twenty-seven patients were studied and at three years, approximately $35 \%$ of patients underwent colectomy. A t six months, $30 \%$ of patients had a flare of ulcerative colitis and by three years, $72 \%$ of patients had flared. These results show that if intravenous cyclosporine can induce remission, oral cycl osporine is not needed as a bridge to long term immunomodulatory therapy with azathioprine. This case illustrates that the clinical expectation for intravenous cyclosporine is complete induction of remission. O ral cyclosporine and infliximab may simply be prolonging the inevitable colectomy.

A nother issue against a prol onged trial of medical therapy is the risk of colorectal cancer in CUC. After longstanding CU C, the risk of colonic dysplasia and cancer increases. It is estimated that after eight to 10 years of $\mathrm{CUC}$, the incidence rate of colorectal cancer increases $0.5 \%$ to $1 \%$ per year. O ne can argue for earlier colectomy in this patient on the basis of the increasing cancer risk. However, despite the risk of colorectal cancer and failure of intravenous cyclosporine, our patient still wanted to avoid surgery for fear of a poor surgical outcome and quality of life. Surgery has been well tolerated in severe pancolitis, but less is known about the tolerability of an ileal pouch anal anastomosis on left sided colitis. Q uality of life studies indicate that those who undergo restorative procto- colectomy and ileal pouch anal anastomosis for pancolitis appear to have the same outcomes as those with left sided colitis (12). Therefore, delaying surgery in the face of medically refractory left sided colitis is not necessary.

The present case illustrates that when a flare of ulcerative colitis results in both steroid and cyclosporine refractory disease, the use of infliximab is limited. Although a transient improvement is seen initially, the response in this case was not durable. C yclosporine should be considered the sal vage therapy in medically refractory disease. Surgery has been studied to be well tolerated, even if the medically refractory disease is limited to the left colon. Furthermore, with the growing risk for dysplasia and colorectal cancer, colectomy remains the treatment of choice in patients with medically refractory disease.

\section{REFEREN CES}

1. Lichtiger S, Present DH, Kornbluth A, et al. Cyclosporine in severe ulcerative colitis refractory to steroid therapy. $N$ Engl J M ed 1994;330:1841-5.

2. Kozarek R, Bedard C, Patterson D, et al. Cyclosporine use in the precolectomy chronic ulcerative colitis patient: A community experience and its relationship to prospective and controlled clinical trials. Pacific N orthwest G astroenterology Society. A m J G astroenterol 1995;90:2093-6.

3. Targan SR, H anauer SB, van Deventer $S J H$, et al. A short-term study of chimeric monoclonal antibody cA 2 to tumor necrosis factor $\alpha$ for C rohn's Disease. N Engl J M ed 1997;337:1029-35.

4. Watkins PE, W arren BF, Stephens S, et al. Treatment of ulcerative colitis in the cottontop tamarin using antibody to tumour necrosis factor al pha. Gut 1997;40:628-33.

5. Sands BE, Tremaine WJ, Sandborn WJ, et al. Infliximab in the treatment of severe, steroid-refractory ulcerative colitis: A pilot study. Inflamm Bowel Dis 2001;7:83-8.

6. Chey W Y, H ussain A, Ryan C, Potter GD, Shah A. Infliximab for refractory ulcerative colitis. A m J G astroenterol 2001;96:2373-81.

7. Probert CSJ, Hearing SD, Schreiber S, Kuhbacher T, G hosh S, Forbes A . Infliximab in steroid-resistant ulcerative colitis: A randomized controlled trial. G astroenterology 2002;122(Suppl 1):A 99. (A bst)

8. Kugathasan S, Prajapati DN, Kim JP, et al. Infliximab outcome in children and adults with ulcerative colitis. G astroenterology 2002;122(Suppl 1):A 615. (A bst)

9. Hyde GM, Thillainayagam AV, Jewell DP. Intravenous cyclosporin as rescue therapy in severe ulcerative colitis: Time for a reappraisal? Eur J G astroenterol Hepatol 1998;10:411-3.

10. C arbonnel F, Boruchowicz A, Duclos B, et al. Intravenous cyclosporine in attacks of ulcerative colitis: Short-term and longterm responses. Dig Dis Sci 1996;41:2471-6.

11. Domenech E, G arcia-Planella E, Bernal I, et al. A zathioprine without oral cyclosporine is enough to maintain long-term remission induced by intravenous cyclosporine in steroid-refractory severe ulcerative colitis. $G$ astroenterology 2002;122(Suppl 1):A 500. (A bst)

12. O oi BS, Remzi F, Preen M, et al. The impact of the extent of disease on the functional outcome and quality of life following restorative proctocolectomy (RP) and ileal pouch-anal anastomosis (IPA A) for mucosal ulcerative colitis (M U C). G astroenterology 2002;122(Suppl 1):A 602. (A bst) 


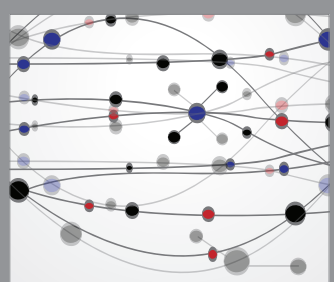

The Scientific World Journal
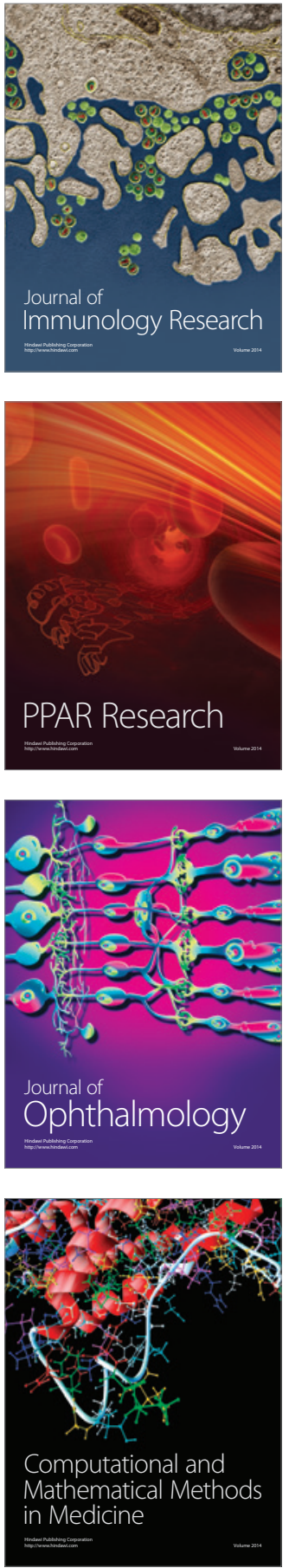

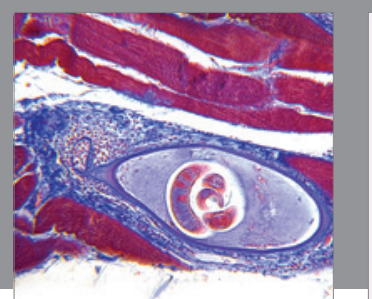

Gastroenterology Research and Practice

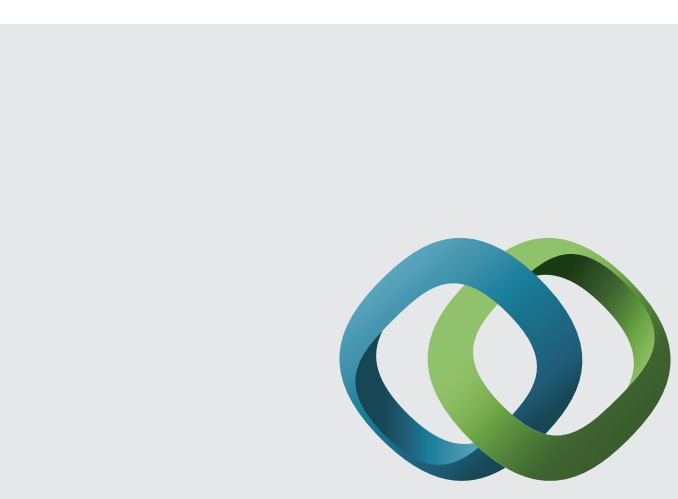

\section{Hindawi}

Submit your manuscripts at

http://www.hindawi.com
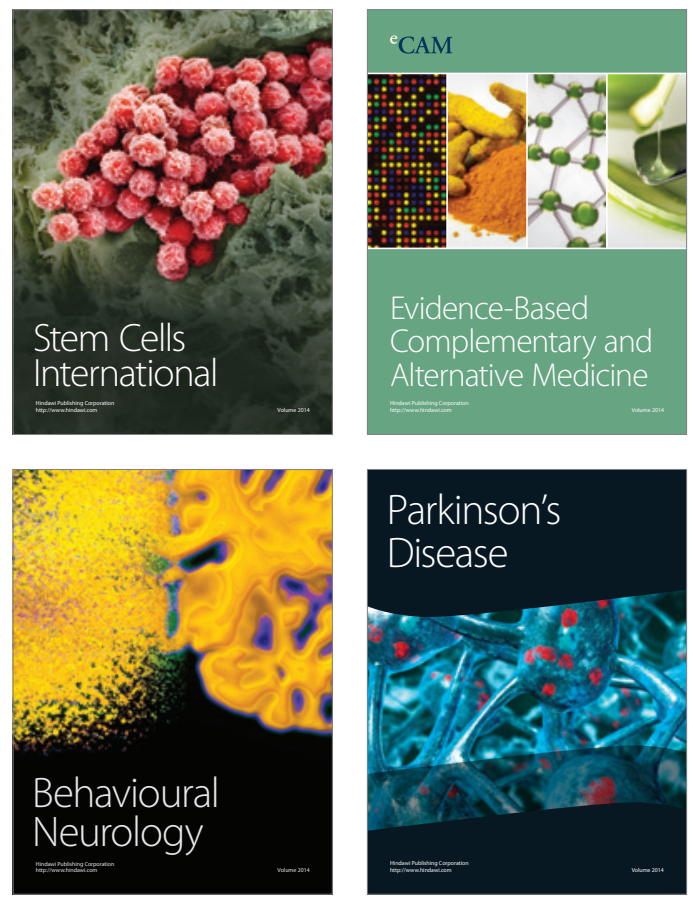
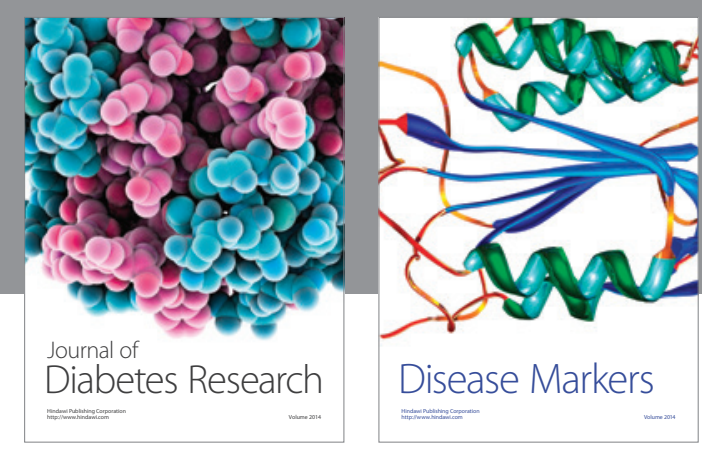

Disease Markers
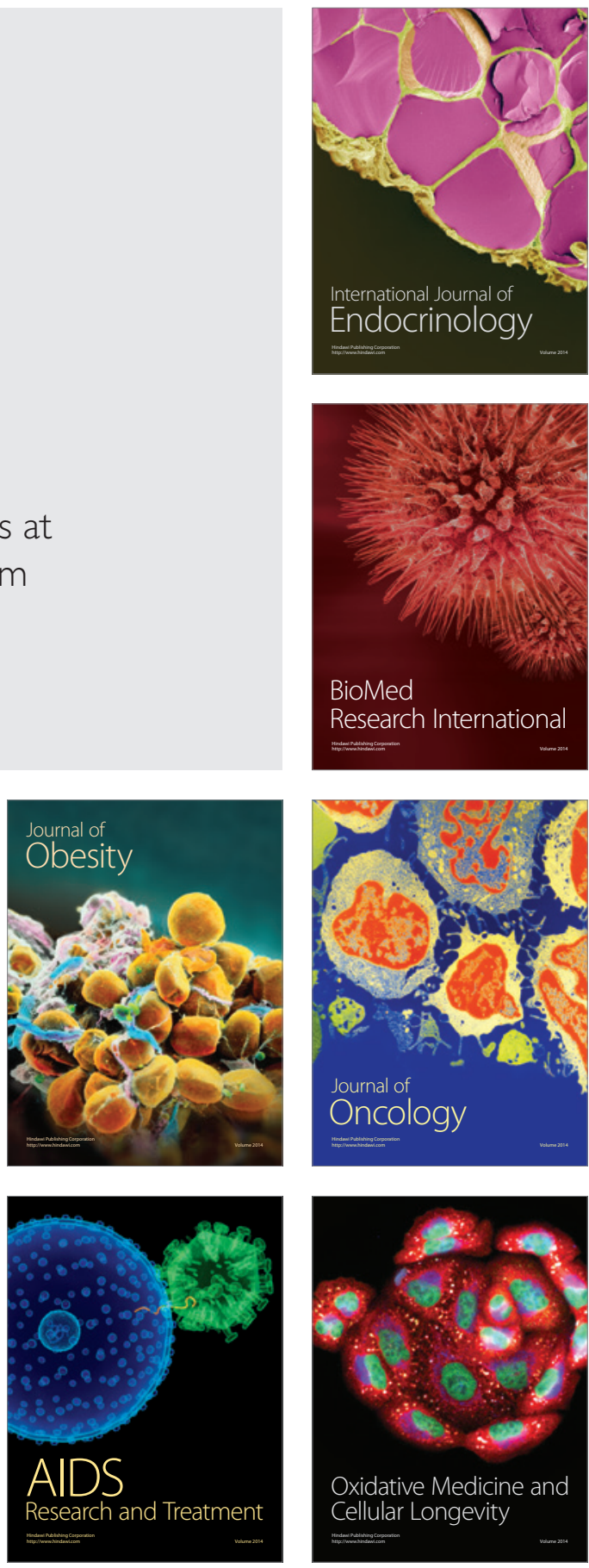